\title{
The Relationship Between Strategic Planning and Budgeting in Regional Development Planning Agency of Sukabumi City
}

\author{
${ }^{1}$ Fahmi Adicipta, ${ }^{2}$ Bayu Kharisma \\ ${ }^{1}$ Development Planning Agency of Sukabumi City, \\ J1. Jalan Sarasa no 9 Sukabumi \\ ${ }^{2}$ Departement of Economics, Universitas Padjadjaran \\ J1. Dipati Ukur No. 35 Bandung, 40132, Indonesia \\ Corespondensi Email : bayu.kharisma@unpad.ac.id
}

\begin{abstract}
This paper aims to analyze whether coordination and synchronization of programs or activities and budgeting in regional development planning agency is possible and lack of synchronization and coordination between SKPD externally so as to affect the quality of development planning. The Relationship Between Strategic Planning and Budgeting Is expected to play a role other than as a control tool, but it can also be used as a performance quality appraisal tool, as well as a tool for the realization of a clean and authoritative government (good governance). There are relationship between strategic planning in Regional Development Planning Agency of sukabumi city (Renstra) and its budgeting. The relationship particularly can be seen in the flow of Renstra (from vision to activities) and the achievement from targets.
\end{abstract}

Keyword : coordination and synchronization, Strategic Planning and Budgeting, good governance

\section{INTRODUCTION}

Bappeda's strategic plan is the implementation of Article 151 paragraph 1 of Law Number 32 Year 2004 regarding Regional Government namely that SKPD develops a strategic plan called Renstra SKPD which contains the vision, mission, goals, strategies, policies, programs and development activities in accordance with its duties and functions Which is guided by the Regional Mid-Term Development Plan (RPJMD) of Sukabumi City Year 2013-2018 and is indicative.

Strategic Planning is a planning process that integrates an organization's major goals, policies and action sequences into a cohesive whole (Mintzberg et.al., 1998). The formulation of a strategic plan is guided by Regulation Of Mayor Sukabumi Number 25 Year 2011 About Control Procedures And Evaluation Regional Development Planning. Starting from the existing provisions, Regional Development Planning Agency of Sukabumi City as one of the technical institutions of Local Government in Sukabumi City Government is required to have strategic plan of SKPD.

Bappeda's strategic plan has a synergistic and implementation relationship with other planning documents, namely regional policy (RPJMD) and budgeting 
policy (APBD). Furthermore, in connection with the financial system as mandated in Law no. 17/2003, the existence of the strategic plan and work plan - Bappeda will serve as guidelines for the preparation of Bappeda's Work Plan and Budget (RKA) which in this connection also the substance of RKA will be reflected in the draft budget and regional expenditure (RAPBD). A solid link between planning and budgeting is a key prerequisite for successful development. Without the linkage, public service provisions can not necessarily meet local demands and still worse, can even be seriously impaired. Further, it is strongly required to institutionalize stakeholder involvements in planning and budgeting processes. Strategic plans and budgets should be kept under constant reviews to be adjusted to economic and political changes.

\subsection{Identification of Problems}

Based on the description set forth above, then the discussion of this article will be limited to some basic issues as follows:

1 Does Coordination and synchronization of programs / activities and budgeting in regional development planning agency is possible.

2 Lack of synchronization and coordination between SKPD externally so as to affect the quality of development planning.

\subsection{Purpose and Objectives}

The purpose of the Strategic Planning and Budgeting in regional development planning agency of Sukabumi Year 2013-2018 are :

1 To ensure the linkage and consistency between planning, budgeting, implementation of programs and activities for each fiscal year for the next 5 (five) years;

2 To ensure the achievement of effective, efficient, and sustainable use of resources.

3 To ensure the creation of integration, synchronization and synergy between development actors. 


\section{LITERATURE REVIEW}

\subsection{Strategic Planning}

Strategic planning is one part of an organization ${ }^{\text {ee }}$ management effort and is seen by some as the principal part of that effort (Poister et al. 2010). Bryson and Roering (1988) define strategic planning as "a disciplined effort to produce fundamental decisions and actions that define what an organization (or other entity) is, what it does, and how it does it" (995). The strategic planning process helps to unify the organization around a common mission, goals, and objectives based upon appropriate internal and external analyses.

Figure 2.1

The mindset strategic planning

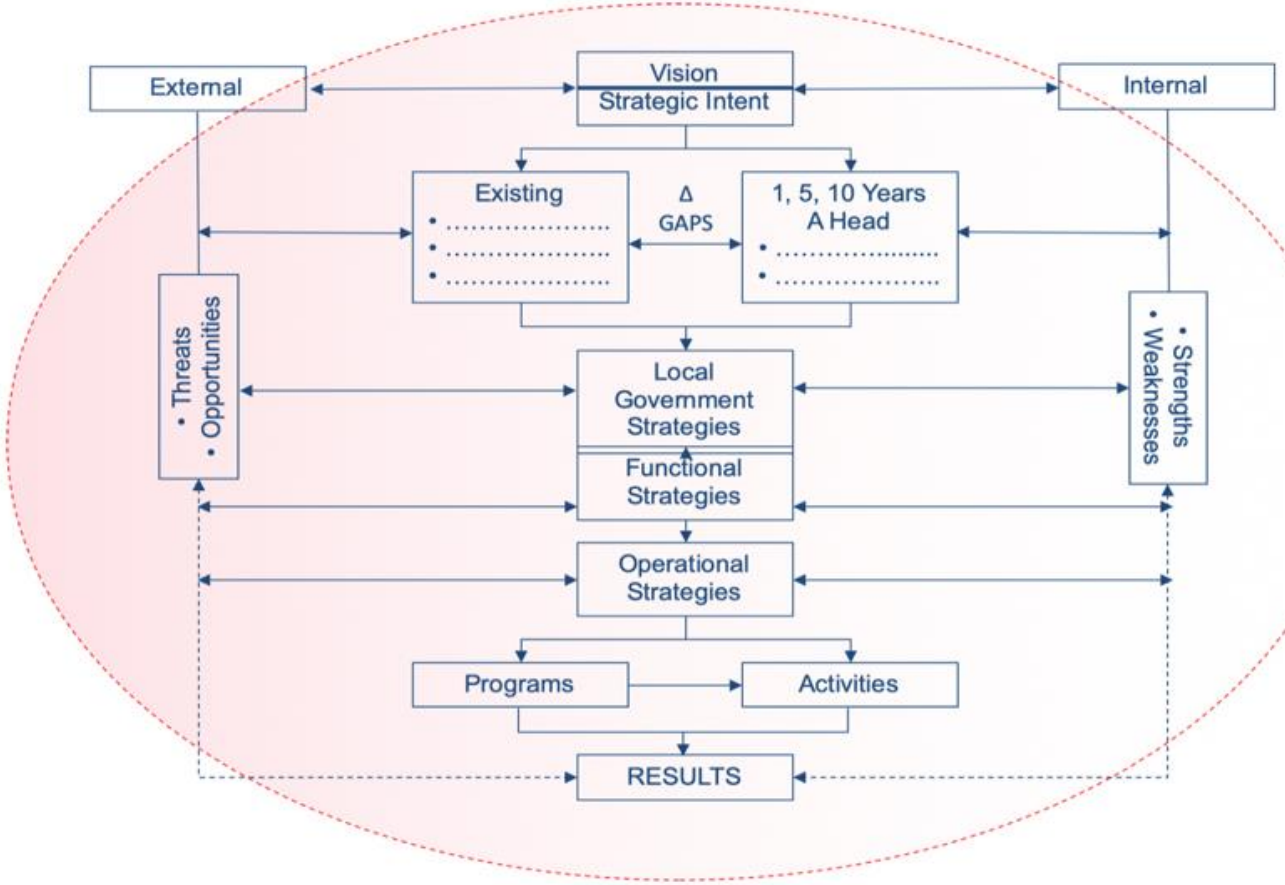

\subsection{Budget}

A budget is a detailed annual plan of how much revenue the local government will raise and how that revenue will be spent in line with the local 
government objectives, needs and priorities (Kitale, 2008). Budgeting is a process of determining the future revenue of a local government for a given period (say one year) and then allocating that revenue between the Local Government needs and priorities (Local Government Act, 1997). The process of budgeting should go hand in hand with the planning process. Local government budget and plans need to reflect priorities and objectives set out in national policy plans and budgets (Local Government Finance And Accountability Act,1998).

\subsection{The relationship planning document and budgeting document}

According to the Local Government Finance And Accountability Regulation Act (1998), the local government planning and budget cycle has to fit into the national planning and budgeting cycle.

\section{Figure 2.2}

The relationship planning document and budgeting document

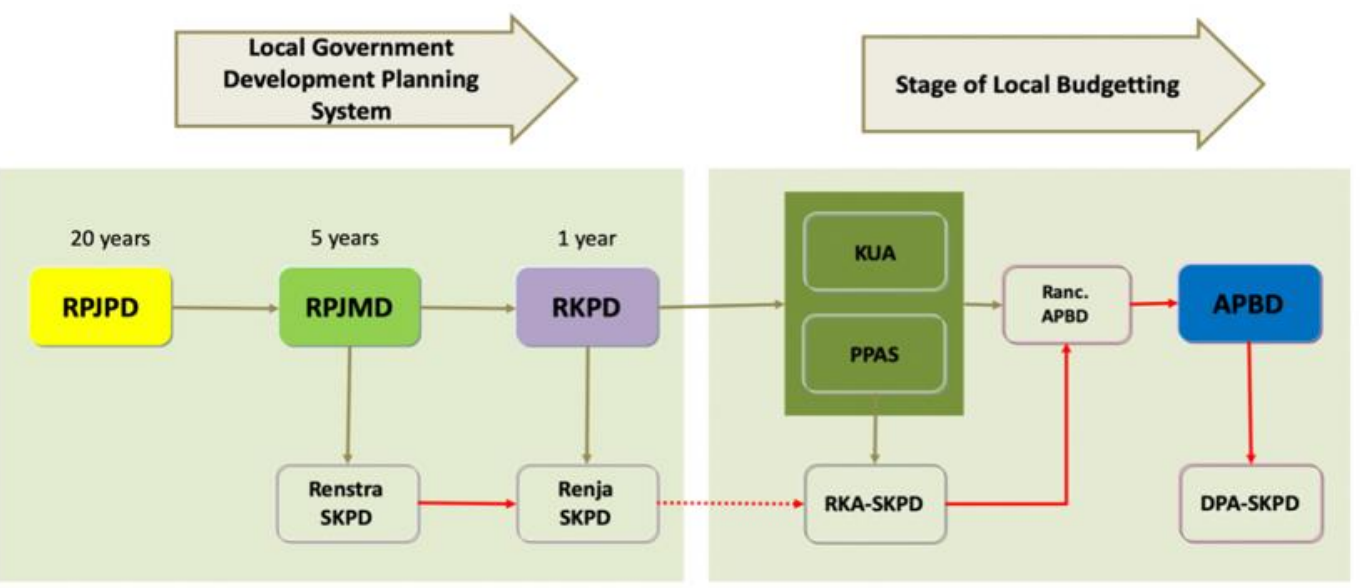

\subsection{Empirical Research}

Usuia \& Alisjahbana (2003) conduct the research about local development planning, budgeting, budget implementation and adjustment in Indonesia based on the first two and a half year's experiences after the 2001 decentralization. Indonesian government needs to make the best strategic use of matching grant allocations to penetrate national priorities and internalize spill over effects into local planning and budgeting. There are some innovative moves with regional 
governments' initiatives to promote active stakeholder participation. However, it is highly important to build in stakeholder involvements into local government structure through provisions in a law. Although about 60 percent of regional governments has shifted to the new budget format since FY2003, concepts of strategic multi-years planning and performance based budgeting are not necessarily well understood by regional governments, where clear indicative targets have not yet been prepared. Linkages between local development plans remain weak, much less linkages between development plans and budgets. Major contributing factors include: 1) lack of general guidelines for local planning; 2) delayed release of new guidelines for local budgeting and financial managements; 3) vague expenditure assignments; and 4) lack of qualified local planning and budgeting officials. In particular, extreme weakness in capacities of local personnel was found in our case studies. Central and provincial governments' strong initiatives in providing coordinated training supports to local governments are most urgently needed.

Julius (2011) The study intended to establish the effect of budgets and work plans on budget performance of Local Governments with a case study of Mukono District Local Government. The major challenges facing Local Governments in full budget absorption were found to be both internal (such as capacity and administrative issues) and external (including amount of funding, time of release of funds, demand vs. supply, and infrastructural challenges). It was finally concluded that Mukono district local government is a fairly credible budget performer and therefore implementer of social services on behalf of the central government but there is need to vigilantly deal with the challenges that lead to under performance on a wider and detailed scope.

Khusaeni (2014) This research explained Consistency of planning and budgeting in local government has become a fundamental concern in Indonesian development. Fiscal decentralisation entails shifting some responsibilities for planning and budgeting to lower levels of government such as district and city. This research aims at investigating and analysing the consistency between planning and budgeting at some districts and cities in Indonesia. Conducted descriptivecomparative analysis indicated that since implementation of fiscal decentralisation 
lead to greater role of local government in determining planning and budgeting. Generally, the consistency of local planning with the national priorities issue is relatively high. However, there is little consistency between RKPD and RAPBD both in programme formulating and budget execution. Conversely, there is a high level of consistency between KUA-PPAS and RAPBD both in programme and budget.

Nurmandi \& Purnomo (2014) examines the implementation of strategic plans in Yogyakarta Special Province (YSP). The visions and missions of the YSP are investigated as a basis of analysis. Using qualitative data and a case study method, the research also conducted in-depth interviews with bureaucrats in YSP. First, YSP attempted to provide the strategic plans to be followed by government officers in their activities according to strategic design and planning school approaches. Second, most local government agencies have poor understanding of their visions and missions. Third, because of the zero-sum game effect, it was difficult to attain the goals and missions. Fourth, the strategic plan has been implemented but not properly executed in the strategic zone, nor did it support the reaching of its missions.

\subsection{Vission, Missions, Goals, Objectives and Key Performance Indicators of regional development Planninga Agency of Sukabumi City}

Vision explained Direction or a future ideal condition to be achieved (clarity of direction) Based on current conditions and situations that create gaps (gaps) Between current and future conditions to be achieved. Vision of strategic plan is a picture of the direction of development or future conditions to be achieved by SKPD through the implementation of duties and functions within a period of 5 (five) years will come. By paying attention to the Main Duty and Function, the vision of the Regional Development Planning Agency of Sukabumi City Year 2013-2018, is “The Realization Of Integrated Regional Development Planning And Control”.

Mission is a general formula of the efforts to be implemented for To realize the vision of Regional Development Planning Agency of the City of Sukabumi. The formulation of strategic plan missions developed by paying attention to several factor Strategic environment, both external and internal that affect (strength, 
Weaknesses, opportunities, and challenges) of regional development. To achieve the Vision there are 3 (three) missions that must be implemented in order to realize the vision of Regional Development Planning Agency of Sukabumi City 2013-2018 are:

- Mission 1 (one) : Creating a Professional Planner Apparatus.

- Mission 2 (two) : Achieve quality planning.

- Mission 3 (three): Improve Control of Implementation of Regional Development.

Goals and Objectives are the phases of formulating strategic targets that indicate levels The highest priority in regional mid-term development planning Will be the basis for the preparation of SKPD performance for five years. Objectives are statements about the things that need to be done to achieve Vision, carry out missions, solve problems, and tackle regional strategic issues To be faced A goal is the expected result of a measurablely formulated goal, Specific, easy to achieve, rational, to be implemented within a period of 5 (five)Year s ahead. For such success, it is necessary to stipulate the goals and objectives of Regional Development Planning Agency of Sukabumi City 2013-2018 as stated in Table 1 and 2 below :

Table 1.

Goals and Objectives of Regional Development Planning Agency of Sukabumi City

\begin{tabular}{|l|ll|}
\hline \multicolumn{1}{|c|}{ Goals } & \multicolumn{1}{c|}{ Objectives } \\
\hline $\begin{array}{l}\text { 1. Improve the professionalism of } \\
\text { apparatus Planners }\end{array}$ & $\begin{array}{l}\text { 1. } \\
\text { Re Increased Competence of Human } \\
\text { Resources Planners }\end{array}$ \\
\hline $\begin{array}{l}\text { Improve System Implementation and } \\
\text { Mechanism of Regional } \\
\text { Development Planning }\end{array}$ & $\begin{array}{l}\text { 2. } \\
\text { Realizing Coordination, Integration, } \\
\text { Synchronization and Participation of } \\
\text { Regional Development Planning }\end{array}$ \\
\hline $\begin{array}{l}\text { 3. Improving the Performance of } \\
\text { Regional Development through } \\
\begin{array}{l}\text { Control, Reporting, Monitoring and } \\
\text { Evaluation, as well as development } \\
\text { data that can be accounted for }\end{array}\end{array}$ & 3. $\begin{array}{l}\text { Controlled implementation of } \\
\text { development in the region }\end{array}$ \\
\hline & 4. Realizing data-driven development \\
\hline
\end{tabular}


Table 2

Goals, Objectives and Achievement Targets

\begin{tabular}{|c|c|c|c|c|c|c|c|c|c|}
\hline \multirow[b]{2}{*}{ Goals } & \multicolumn{3}{|c|}{ Objectives } & \multicolumn{6}{|c|}{ Target } \\
\hline & Objectives & Objectives indicator & Unit & $\begin{array}{l}\text { Initial } \\
\text { conditio } \\
\text { ns(2013) }\end{array}$ & 2014 & 2015 & 2016 & 2017 & $\begin{array}{c}\text { Final } \\
\text { conditio } \\
\text { ns } \\
(\mathbf{2 0 1 8})\end{array}$ \\
\hline $\begin{array}{l}\text { Enhance } \\
\text { Professionalism of } \\
\text { apparatus planners }\end{array}$ & $\begin{array}{l}\text { Increased } \\
\text { Competence of } \\
\text { Human } \\
\text { Resources } \\
\text { Planners }\end{array}$ & $\begin{array}{l}\text { Percentage of } \\
\text { apparatus planners } \\
\text { following the } \\
\text { upgrading of Human } \\
\text { Resources Planners }\end{array}$ & $\%$ & $60 \%$ & $60 \%$ & $65 \%$ & $65 \%$ & $70 \%$ & $70 \%$ \\
\hline \multirow{5}{*}{$\begin{array}{l}\text { Improve System } \\
\text { Implementation and } \\
\text { Mechanism of } \\
\text { Regional } \\
\text { Development } \\
\text { Planning }\end{array}$} & \multirow{5}{*}{$\begin{array}{l}\text { Achieve } \\
\text { Coordination, } \\
\text { Integration, } \\
\text { Synchronization } \\
\text { and } \\
\text { Participation of } \\
\text { Development } \\
\text { Planning in the } \\
\text { region }\end{array}$} & $\begin{array}{l}\text { Percentage of } \\
\text { proposed community } \\
\text { activities that are } \\
\text { accommodated in } \\
\text { RKPD }\end{array}$ & $\%$ & $30 \%$ & $30 \%$ & $30 \%$ & $30 \%$ & $30 \%$ & $30 \%$ \\
\hline & & $\begin{array}{l}\text { Percent Performance } \\
\text { alignment of } \\
\text { performance } \\
\text { indicators Renja } \\
\text { SKPD with RKPD } \\
\text { performance } \\
\text { indicators }\end{array}$ & $\%$ & $85 \%$ & $85 \%$ & $90 \%$ & $90 \%$ & $95 \%$ & $95 \%$ \\
\hline & & $\begin{array}{l}\text { Percent Performance } \\
\text { of RKPD performance } \\
\text { indicators with } \\
\text { RPJMD performance } \\
\text { indicators }\end{array}$ & $\%$ & $85 \%$ & $85 \%$ & $90 \%$ & $90 \%$ & $95 \%$ & $95 \%$ \\
\hline & & $\begin{array}{l}\text { Percentage of } \\
\text { Alignment of Renstra } \\
\text { performance } \\
\text { indicators with } \\
\text { RPJMD performance } \\
\text { indicators }\end{array}$ & $\%$ & $85 \%$ & $85 \%$ & $90 \%$ & $90 \%$ & $95 \%$ & $95 \%$ \\
\hline & & $\begin{array}{l}\text { Percent Performance } \\
\text { alignment of } \\
\text { performance } \\
\text { indicators Renja } \\
\text { SKPD with RKPD } \\
\text { performance } \\
\text { indicators }\end{array}$ & $\%$ & $85 \%$ & $85 \%$ & $90 \%$ & $90 \%$ & $95 \%$ & $95 \%$ \\
\hline
\end{tabular}




\begin{tabular}{|c|c|c|c|c|c|c|c|c|c|}
\hline \multirow{3}{*}{$\begin{array}{l}\text { Improving the } \\
\text { Performance of } \\
\text { Regional } \\
\text { Development } \\
\text { through Control, } \\
\text { Reporting, } \\
\text { Monitoring and } \\
\text { Evaluation, as well } \\
\text { as development data } \\
\text { that can be } \\
\text { accounted for }\end{array}$} & \multirow{3}{*}{$\begin{array}{l}\text { Controlled } \\
\text { implementation } \\
\text { of development } \\
\text { in the region }\end{array}$} & $\begin{array}{l}\text { Percentage of } \\
\text { achievement of the } \\
\text { development target } \\
\text { indicator listed in } \\
\text { RKPD }\end{array}$ & $\%$ & $80 \%$ & $82 \%$ & $84 \%$ & $86 \%$ & $88 \%$ & $90 \%$ \\
\hline & & $\begin{array}{l}\text { Percentage of SKPD } \\
\text { that prepare the } \\
\text { Document of Planning } \\
\text { well }\end{array}$ & $\%$ & $80 \%$ & $80 \%$ & $85 \%$ & $85 \%$ & $90 \%$ & $90 \%$ \\
\hline & & $\begin{array}{l}\text { Percentage of SKPD } \\
\text { that compiled the } \\
\text { Evaluation Document } \\
\text { well }\end{array}$ & $\%$ & $80 \%$ & $80 \%$ & $85 \%$ & $85 \%$ & $90 \%$ & $90 \%$ \\
\hline
\end{tabular}

Source : Strategic planning of Regional Development Planning Agency of Sukabumi City 20132018

\section{DATA AND ANALYSIS METHOD}

\subsection{Analysis of Performance Indicators Achievement approach}

The government's performance accountability system (SAKIP) is an integration of the planning system, budgeting system, and performance reporting system in line with the implementation of the financial accountability system. The annual performance plan is an elaboration of the targets and programs set out in the strategic plan.The measurement of performance achievement level of Bappeda of Sukabumi City in 2016 is done by comparing the target of achievement of the target indicator that has been set in the Performance Determination of Bappeda of Sukabumi City in 2016 with the realization

Table 3.

Performance Indicators Achievement

\begin{tabular}{|c|c|c|c|c|c|c|}
\hline Goals & Objectives & Objectives indicator & Unit & $\begin{array}{c}\text { Target } \\
2016\end{array}$ & $\begin{array}{c}\text { Realization } \\
2016\end{array}$ & $\begin{array}{l}\text { Achievement } \\
\text { performance }\end{array}$ \\
\hline $\begin{array}{l}\text { Enhance } \\
\text { Professionalism of } \\
\text { apparatus planners }\end{array}$ & $\begin{array}{l}\text { Increased } \\
\text { Competence of } \\
\text { Human } \\
\text { Resources } \\
\text { Planners }\end{array}$ & $\begin{array}{l}\text { Percentage of } \\
\text { apparatus planners } \\
\text { following the } \\
\text { upgrading of Human } \\
\text { Resources Planners }\end{array}$ & $\%$ & $65 \%$ & $70 \%$ & $70 \%$ \\
\hline \multirow{2}{*}{$\begin{array}{l}\text { Improve System } \\
\text { Implementation and } \\
\text { Mechanism of } \\
\text { Regional } \\
\text { Development } \\
\text { Planning }\end{array}$} & \multirow{2}{*}{$\begin{array}{l}\text { Achieve } \\
\text { Coordination, } \\
\text { Integration, } \\
\text { Synchronization } \\
\text { and } \\
\text { Participation of } \\
\text { Development }\end{array}$} & $\begin{array}{l}\text { Percentage of } \\
\text { proposed community } \\
\text { activities that are } \\
\text { accommodated in } \\
\text { RKPD }\end{array}$ & $\%$ & $30 \%$ & $30 \%$ & $30 \%$ \\
\hline & & $\begin{array}{l}\text { Percent Performance } \\
\text { alignment of } \\
\text { performance }\end{array}$ & $\%$ & $90 \%$ & $95 \%$ & $95 \%$ \\
\hline
\end{tabular}




\begin{tabular}{|c|c|c|c|c|c|c|}
\hline & \multirow[t]{4}{*}{$\begin{array}{l}\text { Planning in the } \\
\text { region }\end{array}$} & $\begin{array}{l}\text { indicators Renja } \\
\text { SKPD with RKPD } \\
\text { performance } \\
\text { indicators }\end{array}$ & & & & \\
\hline & & $\begin{array}{l}\text { Percent Performance } \\
\text { of RKPD performance } \\
\text { indicators with } \\
\text { RPJMD performance } \\
\text { indicators }\end{array}$ & $\%$ & $90 \%$ & $95 \%$ & $95 \%$ \\
\hline & & $\begin{array}{l}\text { Percentage of } \\
\text { Alignment of Renstra } \\
\text { performance } \\
\text { indicators with } \\
\text { RPJMD performance } \\
\text { indicators }\end{array}$ & $\%$ & $90 \%$ & $95 \%$ & $95 \%$ \\
\hline & & $\begin{array}{l}\text { Percent Performance } \\
\text { alignment of } \\
\text { performance } \\
\text { indicators Renja } \\
\text { SKPD with RKPD } \\
\text { performance } \\
\text { indicators } \\
\end{array}$ & $\%$ & $90 \%$ & $95 \%$ & $95 \%$ \\
\hline \multirow{3}{*}{$\begin{array}{l}\text { Improving the } \\
\text { Performance of } \\
\text { Regional } \\
\text { Development } \\
\text { through Control, } \\
\text { Reporting, } \\
\text { Monitoring and } \\
\text { Evaluation, as well } \\
\text { as development data } \\
\text { that can be } \\
\text { accounted for }\end{array}$} & \multirow{3}{*}{$\begin{array}{l}\text { Controlled } \\
\text { implementation } \\
\text { of development } \\
\text { in the region }\end{array}$} & $\begin{array}{l}\text { Percentage of } \\
\text { achievement of the } \\
\text { development target } \\
\text { indicator listed in } \\
\text { RKPD }\end{array}$ & $\%$ & $86 \%$ & $88 \%$ & $90 \%$ \\
\hline & & $\begin{array}{l}\text { Percentage of SKPD } \\
\text { that prepare the } \\
\text { Document of Planning } \\
\text { well }\end{array}$ & $\%$ & $85 \%$ & $90 \%$ & $90 \%$ \\
\hline & & $\begin{array}{l}\text { Percentage of SKPD } \\
\text { that compiled the } \\
\text { Evaluation Document } \\
\text { well }\end{array}$ & $\%$ & $85 \%$ & $90 \%$ & $90 \%$ \\
\hline
\end{tabular}

Source : LAKIP Regional Development Planning Agency of Sukabumi City 2016

Based on the results of The annual performance plan (RKT) measurements the average results achieved 112.99\%, For example : Achievement of target indicators Percentage of proposed community activities that are accommodated in RKPD also shows a good enough figure of $32 \%$ exceeding the $30 \%$ target or achieving $106.67 \%$ performance, Although it has exceeded the target, the above target should always be improved, it is very important because with the increasing number of community proposals that are accommodated and implemented in development will be able to increase the credibility of the government in public so that it will increase public confidence in the government. While the other target indicator is Percentage of RPJMD Performance Indicators in RKPD defined in RKA / DPA exceeds the target of $90 \%$ with target in 2016 that is $65 \%$. This 
indicates that the planning undertaken by SKPD has been directed, in accordance with what is outlined by the RPJMD, which are the main targets in the development of the city of Sukabumi.

\subsection{Analysis of Budgeting Approach}

The target of budgeting performance is the absorption of the budget that has been determined maximally in the hope that the program / activity that has been planned can be implemented and run in accordance with the planning that has been set. In fiscal year 2016, Regional Development Planning Agency of Sukabumi City get budget allocation of Rp. 11,989,912,675, - consisting of Indirect Expenditures of Rp. 3,876,353,075, - and Direct Expenditure of Rp. 8.113.559.600, -. Total budget realization for 2016 is Rp. 11,621,017,361, - or $96.59 \%$ of the total budget ceiling with details of Direct Expenditure realization amounting to Rp.3.784.801.298, - or 97.63\% and Direct Expenditure of Rp. 7,636,214,063, - or $95.65 \%$.

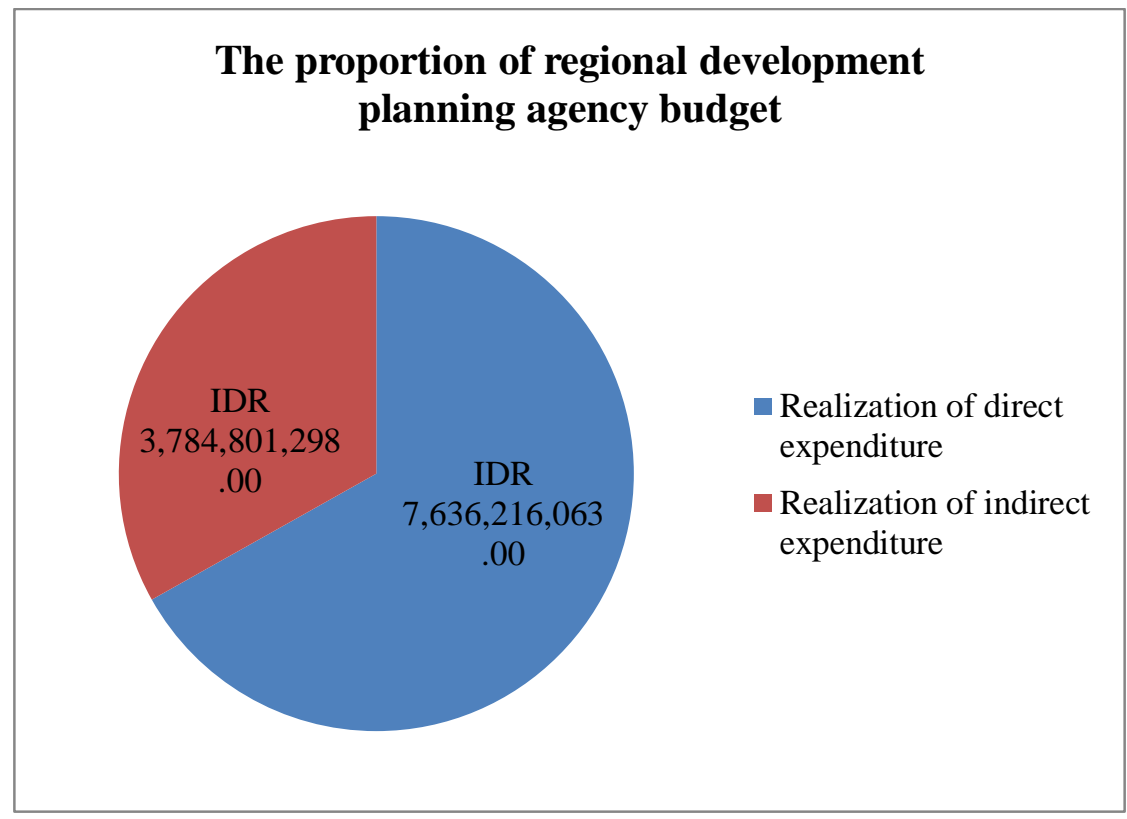

The details of the budget ceiling and the realization of the budget associated with the achievement of target performance goals and targets at each 
Mission Strategic Regional Development Planning Agency of Sukabumi City in 2016 can be seen in the following Table 4:

Table 4.

Mission Strategic Regional Development Planning Agency of Sukabumi City

\begin{tabular}{|l|c|c|c|}
\hline \multicolumn{1}{|c|}{ Program } & Budget & Realization 2016 & $\%$ \\
\hline Program of administration of service & $935,011,700.00$ & $901,210,551.00$ & 96,38 \\
\hline $\begin{array}{l}\text { Program for increasing facilities and } \\
\text { infrastructure apparatus }\end{array}$ & $1,653,854,000.00$ & $1,627,055,721.00$ & 98,37 \\
\hline $\begin{array}{l}\text { Program for increasing capacity of } \\
\text { apparatus resources }\end{array}$ & $60,500,000.00$ & $60,500,000.00$ & 100.00 \\
\hline $\begin{array}{l}\text { Program for increasing capacity of } \\
\text { apparatus resources }\end{array}$ & $162,871,000.00$ & $155,232,000.00$ & 95,47 \\
\hline $\begin{array}{l}\text { Program for improving reporting systems } \\
\text { of performance measurement and finance }\end{array}$ & 28.868 .000 & 25.428 .000 & 90,69 \\
\hline $\begin{array}{l}\text { Data / information development } \\
\text { programs }\end{array}$ & 408.832 .000 & 373.660 .600 & 91,39 \\
\hline Program for partnership cooperation & $100,000,000.00$ & $100,000,000.00$ & 100.00 \\
\hline $\begin{array}{l}\text { Planning program for strategic and } \\
\text { quickly growth area }\end{array}$ & 1.243 .335 .000 & 1.203 .187 .700 & 96,77 \\
\hline $\begin{array}{l}\text { Program for increasing institutional } \\
\text { capacity regional development planning }\end{array}$ & 102.735 .950 & 97.608 .500 & 95,00 \\
\hline $\begin{array}{l}\text { Regional development planning } \\
\text { programs }\end{array}$ & 1.908 .981 .950 & 1.758 .589 .659 & 92,64 \\
\hline $\begin{array}{l}\text { Economic development planning } \\
\text { programs }\end{array}$ & $\mathbf{1 1 . 9 8 9 . 9 1 2 . 6 7 5}$ & $\mathbf{1 1 . 6 2 1 . 0 1 7 . 3 6 1}$ & $\mathbf{9 6 , 5 9}$ \\
\hline $\begin{array}{l}\text { Social culture planning programs } \\
\text { TotaL }\end{array}$ & & 800.982 .882 & \\
\hline & & & 99,54 \\
\hline
\end{tabular}

Source : LPPD Regional Development Planning Agency of Sukabumi City 2016

Based on the results of Budgeting performance measurements, by comparing the realization of the budget to the budget established for the year and expressed as a percentage. The $96.59 \%$ figure is close to $100 \%$ the maximum number of achievements of the expected financial performance targets. 


\subsection{The Relationship Between Performance Indicators Achievement and budgeting realization}

Regional Development Planning Agency of Sukabumi City as a regional technical institution having planning authority area is expected to contribute to the achievement of target in development priority of Sukabumi City Some of the development planning objectives have been achieved very well even exceeded the set target Based on the results of Budgeting performance measurements $96.59 \%$ and The annual performance plan (RKT) measurements that showed the average results achieved $112.99 \%$. Although the field constraints are not easy to achieve due to the dynamics in connecting between development plans and budgets. Major contributing factors include: 1) lack of general guidelines for local development planning; 2) delayed release of new guidelines for local financial managements; 3) vague expenditure assignments (and also obligatory functions of minimum service standards).

\section{CONCLUSION}

The Relationship Between Strategic Planning and Budgeting Is expected to play a role other than as a control tool, but it can also be used as a performance quality appraisal tool, as well as a tool for the realization of a clean and authoritative government (good governance). There are relationship between strategic planning in Regional Development Planning Agency of sukabumi city (Renstra) and its budgeting. The relationship particularly can be seen in the flow of Renstra (from vision to activities) and the achievement from targets.

\section{REFERENCES}

Ssekate Julius (2011). "The Effect of Budgets and Work plans on the performance of Local Governments: A case study of Mukono District Local Government" reasearch report submitted to makerere university

Noriu Usuia and Armida Alisjahbana (2003) "Local Development Planning and Budgeting in Decentralized Indonesia: Update" International Symposium On Indonesia's Decentralization Policy: Problems And Policy Directions 
Mohamad Khusaini (2014)" Local government planning and budgeting process: a case of districts and cities in Indonesia" Int. J. Economic Policy in Emerging Economies, Vol. 7, No. 2, 2014

Sukabumi municipality. (2013). Stategic Planning in Regional Development Planning Agency of sukabumi city, 2013-2018

Sukabumi municipality. (2016). LAKIP of Regional Development Planning Agency of sukabumi city year 2016.

Sukabumi municipality. (2016). LPPD of Regional Development Planning Agency of sukabumi city year 2016 . 